\title{
Bathymetric Distribution of Planktonic Ostracods (Ostracoda; Crustacea) in the Gulf of Oman (Northwest Indian Ocean) in relation to the Oxygen Minimum Zone
}

\author{
Carol Graves and Martin Angel*
}

Natural History Museum, Cromwell Road, London SW7 5BD

Received: Feberuary 17, 2017; Accepted: March 14, 2017; Published: June 12, 2017

*Corresponding author: Natural History Museum, Cromwell Road, London SW7 5BD; E-mail: mvangel37@gmail.com

\begin{abstract}
The composition and abundances of populations of planktonic ostracods have been analysed from a day and a night series of stratified samples collected from the Gulf of Oman during the Northeast monsoon to a maximum depth of $2000 \mathrm{~m}$. The profiles show that the ostracods were strongly affected by the intense Oxygen Minimum Zone (OMZ), which at the time extended down through much of the water column from $80-1000 \mathrm{~m}$. Comparisons with similar profile data at similar latitude in the Northeast Atlantic demonstrate the overwhelming impact of the OMZ on the distributions of the planktonic ostracods. Forty-two species were identified from the Gulf of Oman, far fewer than the 61 species collected in the Northeast Atlantic. The ostracods are detritivores and probably play an important role in modifying midwater fluxes of organic material.
\end{abstract}

Keywords: Myodocopa; Oceanic; Mesozooplankton; OMZ; Zoogeography; Halocyprida; Cypridina;

\section{Introduction}

The quantitative and qualitative bathymetric distributions of halocyprid ostracod assemblages have been well studied in the North Atlantic (Angel, 2010), but not in other oceans. The sampling procedures adopted in the Gulf of Oman were identical to those used for the Atlantic surveys (Angel, 1969, 1979; Angel and Fasham, 1973, 1974, 1975; Angel et al. 2007; Fasham and Angel, 1975), so direct comparisons can be made between the profiles observed. The environment conditions in the Gulf of Oman are markedly different from those in the North Atlantic. In Arabian Sea the seasonal cycle of the monsoon winds results in extreme seasonality in the physical, chemical and biological environment. During the Southwest Monsoon (August-September), the winds blow alongshore persistently in excess of 30 knots (Naqvi et al., 2003) and this results in intensive upwelling both at a series of centres along the Arabian Peninsula in the lea of peninsulas and also further offshore along the axis of the Findlater jet (Boos and Emanuel, 2009). During active upwelling sea surface temperatures at the inshore upwelling
Centres Sea can be lower than $15^{\circ} \mathrm{C}$, and the upwelled water, originating from below the thermocline, introduces nutrient-rich water into the wind-mixed layer (Morrison et al. 1998). These high concentrations of nutrients stimulate extremely high levels of primary production (Rixen and Ittekkot, 2005, Naqvi et al., 2010), which results in sharp increases in organic fluxes. The bacterial decomposition of these high organic fluxes rapidly exhausts the dissolved oxygen concentrations in the water at subthermocline depths. The exhaustion of dissolved oxygen is unusually rapidly because the oxygen concentrations are already low because the subthermocline water mass is Indian Ocean Deep Water is 'old' and already has a depleted oxygen content. This Indian Ocean Deep Water originates as North Atlantic deep water entering the Indian Ocean around the Cape of Good Hope, and so has not been at the surface where its dissolved oxygen content would have been replenished for many months (Morrison et al., 1999). Thus during the South-west monsoon an intense oxygen minimum zone (OMZ) develops.

Conversely during the Northeast Monsoon (December to February) the winds are light and are blow in a direction that is unfavourable for coastal upwelling. Sea surface temperatures warm and the ecosystem in the wind-mixed become oligotrophic. Evaporation rates are high and keep the sea surface temperatures relatively cool. The neighbouring land is very arid and in the absence of rainfall and freshwater run-off sea surface salinities increase, so the density of the surface waters increases so that they sink (Naqvi, et al., 2003). This sinking of the surface waters lowers the base of the oxygen minimum zone (OMZ) to around $1000 \mathrm{~m}$ (Morrison et al., 1999).

Prior to 1990 the little that was known about the deep pelagic fauna of the Arabian Sea was mainly based on the transits of the early exploratory oceanographic voyages, such as by the Tiefsee and the Dana. The existence of the OMZ was only recognized during the John Murray Expedition (1933-1934), and report series of this expedition includes a short paper on the handful of planktonic ostracod species collected (Cannon, 1940). 
Further data on the ostracods was published by George (1969) in a preliminary analysis of the plankton samples collected during the International Indian Ocean Expedition (1959-1965) (IIOE). The IIOE was a multi-vessel expedition during which the biological sampling was extensive geographically and seasonally, but was mostly restricted to sampling the upper $200 \mathrm{~m}$. George's (1969) summarised data from 1223 standardised samples collected in vertical hauls of the Indian Ocean Standard Net $0.32 \mathrm{~mm}$ mesh) from $200-0 \mathrm{~m}$. George reported that in the North Arabian Sea abundances of halocyprid ostracods peaked during the Northeast monsoon. Leveau (1967) also reported on a collection of halocypids from the Arabian Sea, and there have been a few follow-up studies of the halocyprids (James, 1975, George and Nair 1980, Nair and Madhupratap, 1984). Information about the region's planktonic ostracod assemblages remained sparse until Drapun and Smith (2012) published their excellent monograph summarising the halocyprid results from the 1995 JGOFS Indian Ocean Experiment (Smith and Madhuptratap, 2005). Their sampling using a MOC1 sampler was limited to the upper $1000 \mathrm{~m}$, but their geographical coverage was extensive.

In 1994 a study of the cross-slope relationships between the biological populations in the euphotic zone and the oxygen minimum zone off the coast of Oman was undertaken during the Southwest Monsoon (Herring et al., 1998). Detailed observations were made on the vertical distributions of micronektonic species at three cross-shelf stations close to $19^{\circ} \mathrm{N} 59^{\circ} \mathrm{E}$, and the sampling was supplemented with profiles of backscatter intensity from an Acoustic Doppler Current Profiler (ADCP) (Roe et al., 1996). This samplng revealed exceptionally large, but species-poor populations of micronekton (fish, decapods and euphausiids). Many of the micronektonic species were undertaking diel migrations moving from daytime depths within the OMZ up into the epipelagic zone to feed at night (Herring et al., 1998). At the time there were large swarms of the predatory swimming crab Charybdis smithii (Van Couwelaar, et al., 1997); the crabs were entirely restricted to the upper well-oxygenated waters in the wind-mixed layer. The ADCP surveys revealed strong acoustic backscatter from within the OZM during the day, but at night it became totally devoid of sound-scatterers. All of the back scatterers had migrated up into the wind-mixed layer above 70 m (see figure 13 in Herring et al., 1998). Unfortunately during this cruise, heavy seas and technical problems with the nets prevented complete sampling of mesozooplankton profiles.

In 1997 during the "Scheherazade" cruise aboard the RRS Charles Darwin (Herring et al, 1999), another attempt was made to characterise the mesoplanktonic populations and biological processes during the post-upwelling regime of the Northeast Monsoon in the Gulf of Oman. The cruise had the two main aims -

1.To describe quantitatively and qualitatively the structure of the pelagic assemblages.

2.To assess the impact of the OMZ has on the pelagic assemblages and their diel vertical migrations.

In this paper we report on the data gathered for the halocyprid ostracods, on how the changes in total ostracod abundances are related to the gradients of the physico-chemical parameters, and how the species composition of the assemblages change with depth. Comparisons are made between similar bathymetric profiles of planktonic ostracods from comparable latitude in the Northeast Atlantic, which demonstrates the severity of the restrictions the $\mathrm{OMZ}$ poses on the ostracod populations.

\section{Material and Methods}

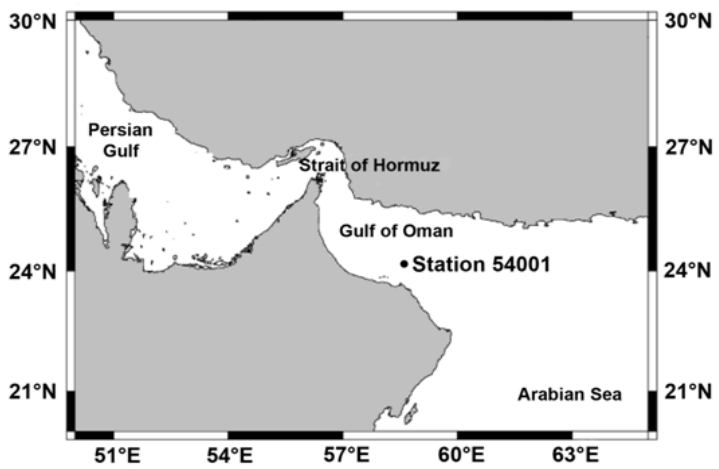

Figure 1: Outline map of the Gulf of Oman showing the sampling position.

The observations were made at Discovery station 54001 (24ำ $\left.12^{\prime} \mathrm{N}, 58^{\circ} 40^{\prime} \mathrm{E}\right)$ (Figure 1) between 23rd and 25th February 1997. The total water column was systematically sampled both by day and by night to a depth of $1000 \mathrm{~m}$ using the multiple rectangular midwater trawl (RMT1+8) (Roe and Shale, 1979; Roe et al., 1980). The profiles were extended deeper to 1000-1400 $\mathrm{m}$ by day and to $1400-2000 \mathrm{~m}$ by night. Studies in the Atlantic had demonstrated that diel vertical migrations by the planktonic ostracods are restricted to the upper $1000 \mathrm{~m}$ (Angel et al., 1982), so it was assumed that the data from below $1000 \mathrm{~m}$ will not have changed either quantitatively or qualitatively during the day/ night cycle. The volumes of water filtered during each tow were estimated from flow meter data, and the physical and chemical characteristics of the water column were profiled nearby using a Conductivity, Temperature Depth probe (CTD) fitted with an oxygen sensor and a fluorometer.

The sampling protocol was to subdivide the upper $200 \mathrm{~m}$ of the water column into $50 \mathrm{~m}$ depth horizons and from 200-1200 m into $100 \mathrm{~m}$ horizons, and below $1200 \mathrm{~m}$ into 200 $\mathrm{m}$ horizons. Most tows were of one hour duration, during which approximately $2500 \mathrm{~m}^{3}$ of water would have been filtered. However, since the daytime sample in the upper $150 \mathrm{~m}$ were so massive, the durations of the night time tows were reduced to 30 minutes. Below $1200 \mathrm{~m}$ the tow durations were increased to two hours.

The samples were initially preserved in buffered $5 \%$ seawater formalin for $24 \mathrm{~h}$, before being transferred into Steadman's preserving fluid $(0.5 \%$ propylene phenoxetol, $4.5 \%$ propylene glycol, $5 \%$ formalin seawater solution) for long term 
storage. Several months later the samples were transferred to the Natural History Museum, London, where prior to sorting the Steadman's preserving fluid was replaced with $80 \%$ industrial methylated ethanol.

The halocyprids were generally sorted from the complete samples under a stereoscopic microscope. After the night sample from 150-100m yielded over 19,000 individuals, the remaining shallow samples were subsampled using a Folsom splitter. Identifications were made using a Wild M5 stereomicroscope at x50 magnification. Each species was separated into males, females and juvenile instars, before being counted and measured.

\section{Result}

\section{The Physico-chemical Environment}

Table 1 summarises the profile data for the mean temperature, salinity and oxygen concentrations within each of the sampling horizons derived from the CTD, and the profiles are plotted in Figure 2. The isothermal wind mixed layer extended down to 70-80 m. Below $100 \mathrm{~m}$ water temperature declined almost linearly with depth to $2000 \mathrm{~m}$. Salinities similarly declined apart from a small salinity maximum between 200 and $400 \mathrm{~m}$, the result of the outflow of Persian Gulf Water. Oxygen concentrations were high within the wind-mixed layer, but diminished rapidly from $121.8 \mu \mathrm{M}$ at $78 \mathrm{~m}$ to only $4.7 \mu \mathrm{M}$ at $102 \mathrm{~m}$. At $100-150 \mathrm{~m}$ the mean oxygen concentration was only $3.2 \mu \mathrm{M}$, and decreased even further to a minimum of $<2 \mu \mathrm{M}$ between 362-566 m. Below $600 \mathrm{~m}$ the oxygen concentrations increased very gradually with increasing depth to $10 \mu \mathrm{M}$ at a depth of $1100 \mathrm{~m}$. The oxygen concentrations then rose slightly more quickly to reach $84.9 \mu \mathrm{M}$ at a depth of $2000 \mathrm{~m}$. Chlorophyll concentrations were maximum ( $2.0 \mathrm{mg} . \mathrm{l}^{-1}$ ) at $14 \mathrm{~m}$, and declined to $0.12 \mathrm{mg} . \mathrm{l}^{-1}$ at $70 \mathrm{~m}$, and were negligible at deeper depths.

\begin{tabular}{|c|c|c|c|}
\hline Depth range(m) & Mean salinity $(\% 0)$ & Mean Temperature $\left({ }^{\circ} \mathrm{C}\right)$ & Mean oxygen concentration $\left(\mathrm{ml}^{-\mathrm{l}^{-1}}\right)$ \\
\hline $0-50$ & 36.48 & 23.14 & 204.4 \\
\hline $100-150$ & 36.03 & 19.43 & 3.3 \\
\hline $150-200$ & 36.11 & 18.45 & 2.5 \\
\hline $200-300$ & 36.23 & 17.04 & 2.8 \\
\hline $300-400$ & 36.16 & 15.27 & 2.7 \\
\hline $400-500$ & 35.92 & 13.61 & 1.5 \\
\hline $500-600$ & 35.74 & 12.33 & 1.9 \\
\hline $600-700$ & 35.66 & 11.53 & 3.1 \\
\hline $700-800$ & 35.60 & 10.78 & 5.2 \\
\hline $800-900$ & 35.54 & 10.05 & 6.5 \\
\hline $1000-1100$ & 35.39 & 8.49 & 8.9 \\
\hline $1100-1200$ & 35.30 & 7.70 & 11.4 \\
\hline $1200-1400$ & 35.18 & 6.58 & 19.6 \\
\hline $1400-1600$ & 35.07 & 5.41 & 35.5 \\
\hline $1600-1800$ & 34.95 & 4.13 & 58.8 \\
\hline $1800-2000$ & 34.88 & 3.31 & 76.7 \\
\hline
\end{tabular}

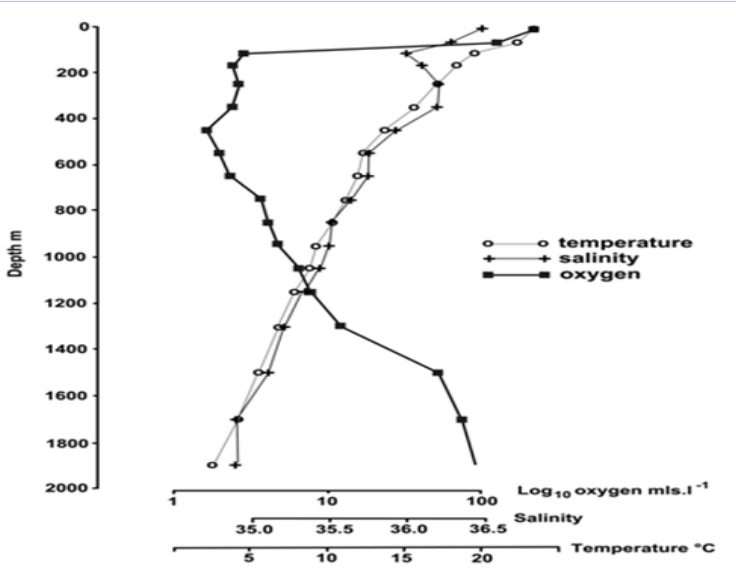

Figure 2: Profiles of the physico-chemical parameters at the sampling position.

\section{Profiles of total ostracod abundances}

The total numbers of ostracods sorted and analysed from the day and night series were 19545 and 39761 respectively. The lower daytime abundances were principally the result of the subsampling. The planktonic ostracods included both halocyprid and myodocopid species. In the upper $200 \mathrm{~m}$ the ostracod assemblage was dominated by a Cypridina sp. - a myodocopid which is poorly known taxonomically. This species forms dense swarms in the region, which generate impressive displays of bioluminescence. The ostracod abundances expressed as numbers per $1000 \mathrm{~m}^{3}$ of water filtered are listed in Table 2 , and the profiles are plotted in figure 3 together with the oxygen concentrations. In the upper $200 \mathrm{~m}$, halocyprid abundances were high 3-4 $\mathrm{m}^{-3}$ and if the Cypridina data are included they are $4-5 \mathrm{~m}^{-3}$. 


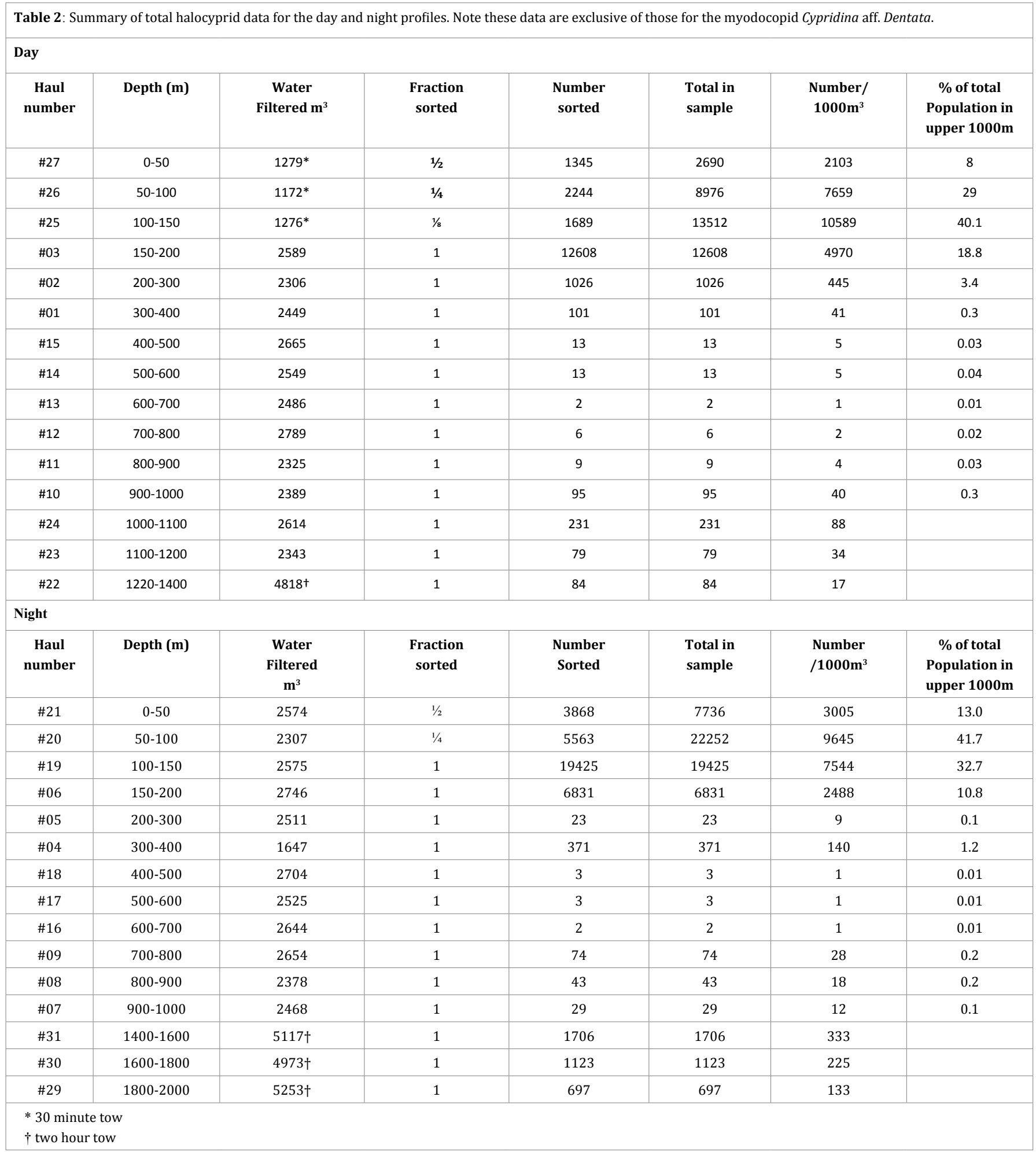




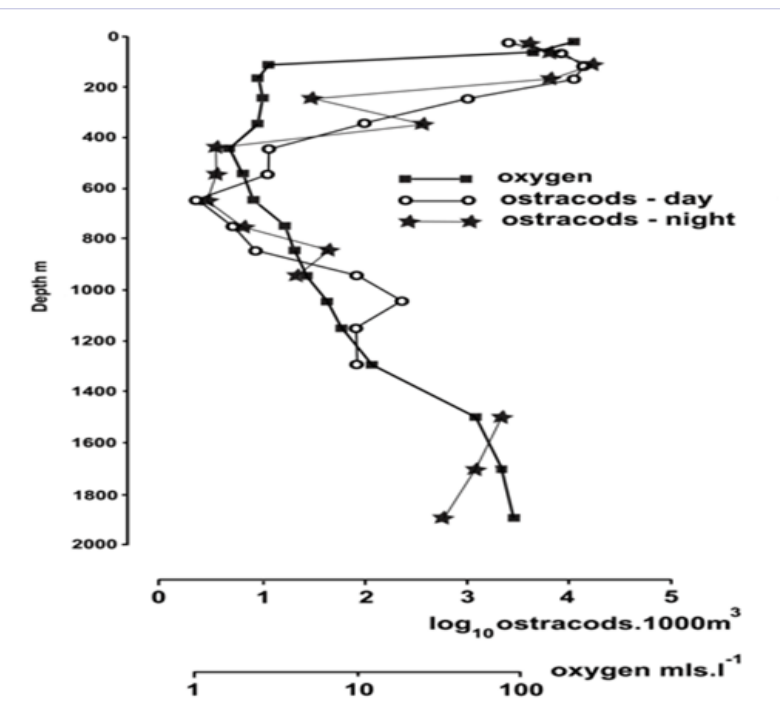

Figure 3: Profiles comparing the oxygen concentrations and the day and night abundances of the ostracods. These show that the abundance profiles while being similar to that of the oxygen profiles show no correspondence at depths of $100-400 \mathrm{~m}$.

Their abundances remained exceptionally high down through the top of the thermocline and the oxycline to depths of $200 \mathrm{~m}$ where the oxygen concentrations had fallen to $2.5-3.3 \mu \mathrm{M}$. Below $200 \mathrm{~m}$ ostracod densities declined abruptly to almost zero, and remained exceptionally low to below $1000 \mathrm{~m}$, but then their adundances began to increase very gradually; it was not until the oxygen concentrations had risen to $>20 \mu \mathrm{M}$ that the halocyprid densities became comparable to those in the North Atlantic. Estimates of total ostracod abundance per $\mathrm{m}^{2}$ in the upper $1000 \mathrm{~m}$ were respectively 799 by day and 611 by night - reasonably similar. Excluding the data for Cypridina, the estimates become even closer - 456 and 512 respectively.

Table 2 lists the estimated percentages of the total halocyprid population in the upper $1000 \mathrm{~m}$ occurring within each sampling stratum. These profiles suggest that there was a slight upward migration at night - the median depth of the halocyprid population in the upper $1000 \mathrm{~m}$ rose from $108 \mathrm{~m}$ by day to $92 \mathrm{~m}$ at night. There was a small increase in numbers at $300-400 \mathrm{~m}$ at night, suggesting some species may have been undertaking a reverse migration, moving deeper into the $\mathrm{OMZ}$ at night.

\section{Species composition and profiles}

The majority of the specimens were identified; the proportion of unidentifiable specimens (mostly juveniles) increased with depth, but never exceeded $5 \%$ of the total catch. The total number of halocyprid species was 41 plus the single myodocopid species (see Table 3). Tables 4-6 list the abundances of females, males and juveniles of each species, expressed as numbers per $1000 \mathrm{~m}^{3}$. Only 16 species were collected by day in the upper $800 \mathrm{~m}$ and 15 by night. Whereas at $1000-1400 \mathrm{~m}$ immediately below the OMZ, 22 species were identified; of which ten had not been encountered in the upper $1000 \mathrm{~m}$. At night at 1400-2000 m 28 species were identified, of which only ten had been collected from above $1000 \mathrm{~m}$.

\section{Discussion Validity of data based on single samples}

In the North Atlantic several series of replicated samples collected at several depths (Angel 1984, Angel, et al. 1982; Angel, unpublished data) showed that at $600 \mathrm{~m}$ or deeper that the overall abundances of halocyprid populations differed by $<25 \%$ between samples irrespective of the time of day, and the species composition and the rank order of species abundance remained the same. This leads to the conclusion that diel vertical migration by ostracods is almost entirely restricted to the upper $600 \mathrm{~m}$. So in the Gulf of Oman, where no evidence of spatial heterogeneity resulting from mesoscale eddies was observed, we feel justified in assuming that the single samples are providing representative data on the species composition, rank order of abundance, and bathymetric profiles of the individual species.

\section{Estimates of abundance of individual species}

The mesh size of the RMT1 sampler is $0.32 \mathrm{~mm}$ and the minimum carapace length of the ostracods it retains is about $0.5 \mathrm{~mm}$. Thus adults of all the halocyprid species will have been fully retained, with the exception of the males of Archiconchoecia striata. For those species with adult carapace lengths $>2 \mathrm{~mm}$, the last three juvenile instars (A-1 to A-3) will have been retained, but these juveniles stage of the smaller will have been extruded through the mesh. This compromises the accuracy of the overall estimates of halocyprid abundances. The accuracy would potentially be increasd by using a finer meshed sampler (e.g. Drapun and Smith, 2012), However since the early juvenile instars cannot be identified there would not have been any improvement in the precision of the individual species data. In addition the time taken to process the total samples would have been substantially increased so that even more sub-sampling would have been needed.

\section{Species composition}

The abundant populations in the upper $100 \mathrm{~m}$ in the Gulf of Oman were dominated by small species $(<2 \mathrm{~mm})$ namely Euconchoecia omanensis, Porroecia porrecta, Pseudoconchoecia concentrica, and Cypridina sp. By night, 95\% of the ostracod sampled consisted of species that brood their embryos within the carapace (i.e. the species of Euconchoecia and Cypridina). This is in stark contrast to the halocyprid populations in the North Atlantic where the brooding species are either absent or rare. Just below the oxycline at $100-200 \mathrm{~m}$, these species were partially replaced by Proceroecia procera, Discoconchoecia elegans, Metaconchoecia acuta and Conchoecetta giesbrechti. These are species must be able to tolerate prolonged exposure to very low oxygen concentrations. Below $200 \mathrm{~m}$, both sample sizes and the numbers of species caught declined sharply. At 200-400 m, within the salinity maximum associated with the outflow of Persian Gulf Water, the small ostracod population was dominated by Conchoecetta giesbrechti and Metaconchoeciainflata. Metaconchoeciainflatawas the only species, to occur almost exclusively below $150 \mathrm{~m}$, and so seemed permanently to occupy water almost devoid of 
Table 3: List of the 41 species of halocyprid and the one modocopid species identified. $†$ Species not recorded in Drapun and Smith (2012) because they did not sample deep enough. * Species not recorded by Drapun and Smith (2012) either because of differences in taxonomic interpretation (i.e. Metaconchoecia and Euconchoecia spp) or because the species is a myodocopid (Cypridina aff, dentata).

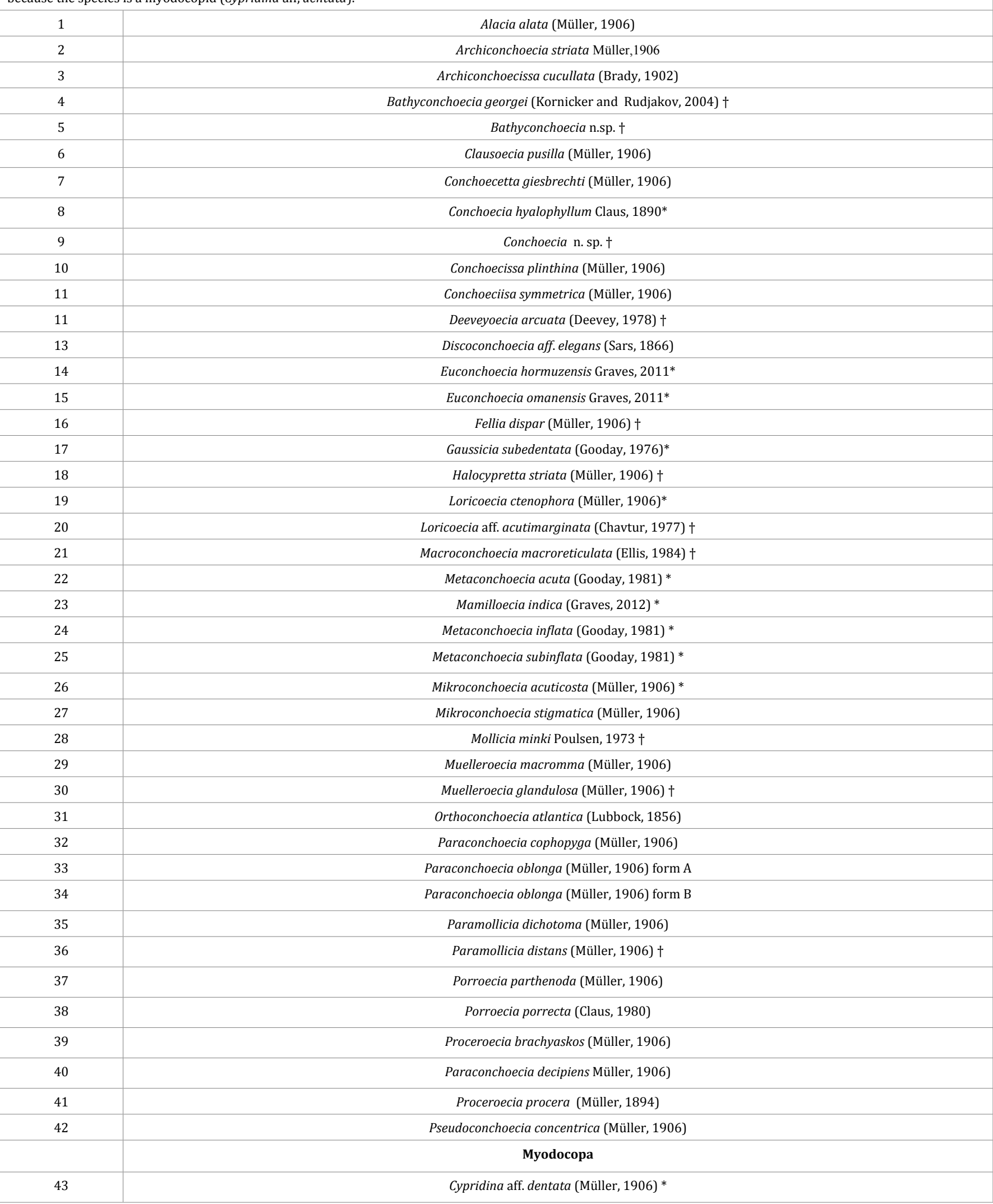




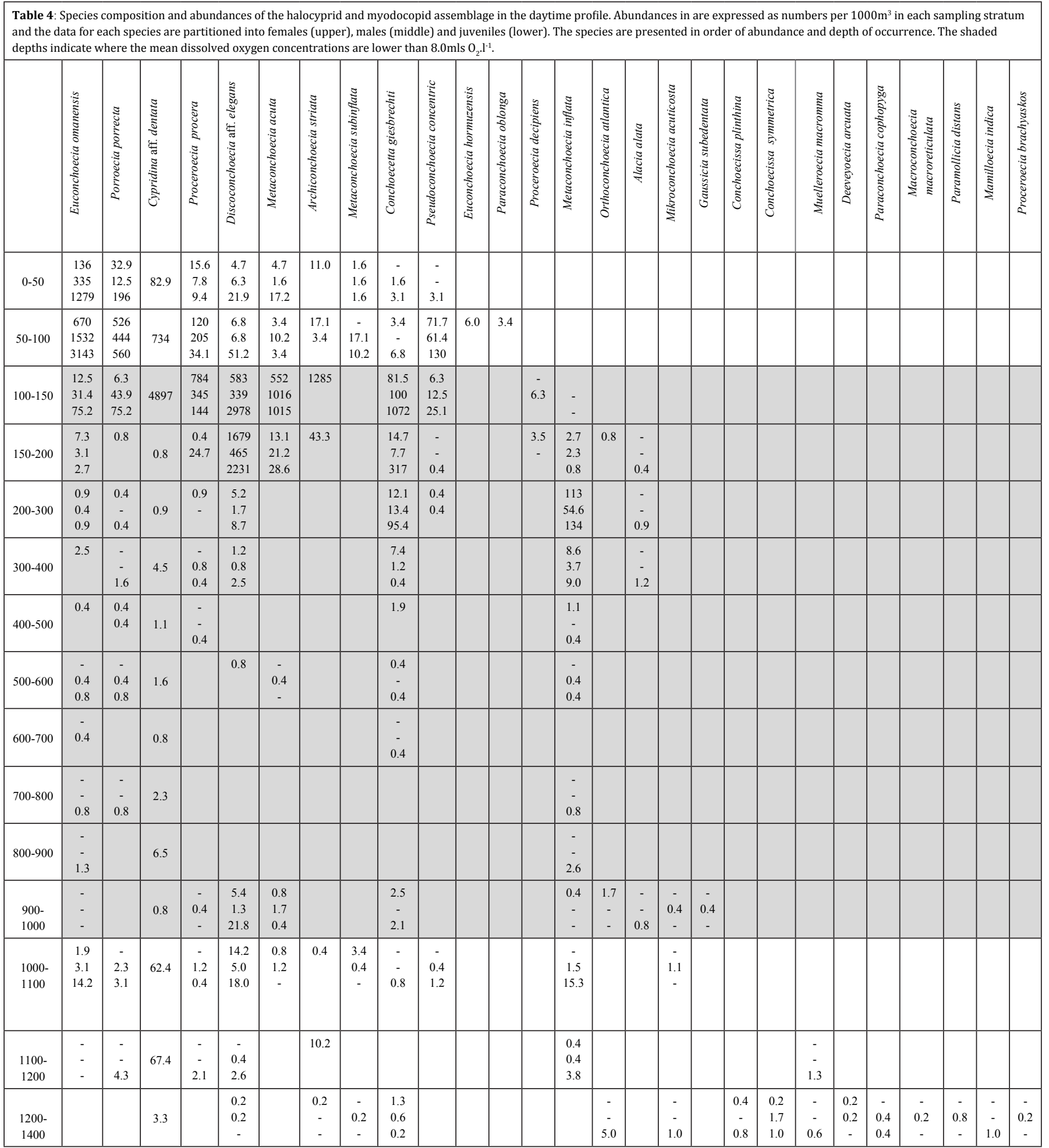


Table 5: Nighttime species abundances in numbers. $1000 \mathrm{~m}^{3}$ in each sampling stratum in the upper $1000 \mathrm{~m}$ partitioned into females (upper), males (middle) and juveniles (lower)

\begin{tabular}{|c|c|c|c|c|c|c|c|c|c|c|c|c|c|c|c|}
\hline 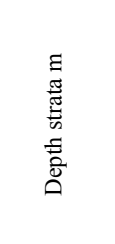 & 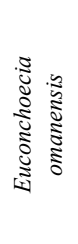 & 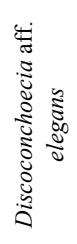 & 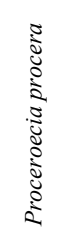 & 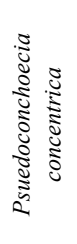 & 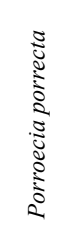 & 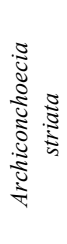 & 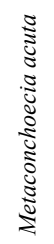 & 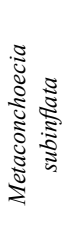 & 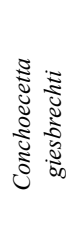 & 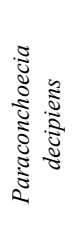 & 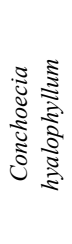 & 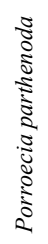 & 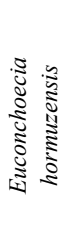 & 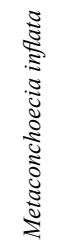 & 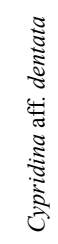 \\
\hline $\begin{array}{l}0- \\
50\end{array}$ & $\begin{array}{c}573 \\
582 \\
1335\end{array}$ & $\begin{array}{l}163 \\
3.1 \\
137\end{array}$ & $\begin{array}{c}97.9 \\
6.2 \\
1.6\end{array}$ & $\begin{array}{l}24.1 \\
21.8 \\
12.4\end{array}$ & $\begin{array}{c}2.3 \\
2.3 \\
13.2\end{array}$ & $\begin{array}{c}14.0 \\
- \\
-\end{array}$ & $\begin{array}{l}4.7 \\
2.3 \\
2.3\end{array}$ & $\begin{array}{c}- \\
0.8 \\
-\end{array}$ & $\begin{array}{c}- \\
- \\
3.9\end{array}$ & $\begin{array}{l}- \\
- \\
-\end{array}$ & $\begin{array}{c}- \\
0.8 \\
0.8\end{array}$ & $\begin{array}{c}0.8 \\
- \\
-\end{array}$ & $\begin{array}{l}- \\
- \\
-\end{array}$ & $\begin{array}{l}- \\
- \\
-\end{array}$ & 2605 \\
\hline $\begin{array}{l}50- \\
100\end{array}$ & $\begin{array}{c}575 \\
704 \\
1522\end{array}$ & $\begin{array}{l}211 \\
20.8 \\
303\end{array}$ & $\begin{array}{c}1564 \\
607 \\
414\end{array}$ & $\begin{array}{l}13.9 \\
22.5 \\
64.2\end{array}$ & $\begin{array}{c}541 \\
477 \\
1905\end{array}$ & $\begin{array}{c}603 \\
- \\
-\end{array}$ & $\begin{array}{c}6.9 \\
- \\
-\end{array}$ & $\begin{array}{c}23 \\
6.9 \\
-\end{array}$ & $\begin{array}{l}1.7 \\
5.2 \\
1.7\end{array}$ & $\begin{array}{c}12.1 \\
5.2 \\
-\end{array}$ & $\begin{array}{c}- \\
- \\
2.8\end{array}$ & - & $\begin{array}{c}17.8 \\
15.6 \\
-\end{array}$ & - & 420 \\
\hline $100-150$ & $\begin{array}{l}4.3 \\
2.3 \\
9.3\end{array}$ & $\begin{array}{c}1198 \\
218 \\
1391\end{array}$ & $\begin{array}{l}435 \\
656 \\
111\end{array}$ & $\begin{array}{l}17.9 \\
16.3 \\
36.1\end{array}$ & $\begin{array}{c}157 \\
161 \\
48.2\end{array}$ & $\begin{array}{c}1135 \\
- \\
-\end{array}$ & $\begin{array}{l}788 \\
309 \\
376\end{array}$ & $\begin{array}{l}1.6 \\
0.4 \\
0.4\end{array}$ & $\begin{array}{l}116 \\
148 \\
164\end{array}$ & $\begin{array}{c}9.3 \\
14.4 \\
3.9\end{array}$ & $\begin{array}{l}0.4 \\
6.2 \\
2.8\end{array}$ & $\begin{array}{c}1.2 \\
0.8 \\
-\end{array}$ & $\begin{array}{l}- \\
-\end{array}$ & - & 45.8 \\
\hline $150-200$ & $\begin{array}{l}1.5 \\
1.1 \\
0.4\end{array}$ & $\begin{array}{l}854 \\
503 \\
832\end{array}$ & $\begin{array}{c}2.6 \\
52 \\
-\end{array}$ & - & - & $\begin{array}{c}52.4 \\
- \\
-\end{array}$ & $\begin{array}{l}20 \\
16 \\
22\end{array}$ & $\begin{array}{l}- \\
- \\
-\end{array}$ & $\begin{array}{l}6.2 \\
4.7 \\
111\end{array}$ & - & $\begin{array}{l}- \\
- \\
-\end{array}$ & $\begin{array}{l}- \\
- \\
-\end{array}$ & - & $\begin{array}{c}1.5 \\
- \\
-\end{array}$ & 2.5 \\
\hline $200-300$ & $\begin{array}{c}- \\
- \\
0.4\end{array}$ & $\begin{array}{c}0.4 \\
- \\
-\end{array}$ & $\begin{array}{c}0.4 \\
- \\
-\end{array}$ & - & - & $\begin{array}{l}- \\
- \\
-\end{array}$ & $\begin{array}{l}- \\
-\end{array}$ & $\begin{array}{l}- \\
-\end{array}$ & $\begin{array}{c}- \\
- \\
0.4\end{array}$ & - & - & $\begin{array}{l}- \\
-\end{array}$ & - & $\begin{array}{l}0.4 \\
2.8 \\
4.0\end{array}$ & 1.2 \\
\hline $300-400$ & $\begin{array}{c}1.5 \\
- \\
-\end{array}$ & $\begin{array}{c}1.9 \\
0.4 \\
-\end{array}$ & $\begin{array}{c}- \\
- \\
0.4\end{array}$ & $\begin{array}{l}- \\
- \\
-\end{array}$ & $\begin{array}{c}0.4 \\
- \\
0.4\end{array}$ & $\begin{array}{c}0.4 \\
- \\
-\end{array}$ & $\begin{array}{l}- \\
-\end{array}$ & $\begin{array}{l}- \\
-\end{array}$ & $\begin{array}{l}2.3 \\
0.4 \\
0.4\end{array}$ & - & - & $\begin{array}{l}- \\
- \\
-\end{array}$ & - & $\begin{array}{l}27.2 \\
40.8 \\
61.6\end{array}$ & 3.4 \\
\hline $400-500$ & $\begin{array}{l}- \\
-\end{array}$ & - & - & - & $\begin{array}{c}0.4 \\
- \\
0.7\end{array}$ & $\begin{array}{l}- \\
- \\
-\end{array}$ & $\begin{array}{l}- \\
-\end{array}$ & $\begin{array}{l}- \\
-\end{array}$ & $\begin{array}{l}- \\
-\end{array}$ & - & - & $\begin{array}{l}- \\
-\end{array}$ & - & - & 0.7 \\
\hline $500-600$ & $\begin{array}{l}- \\
-\end{array}$ & $\begin{array}{c}- \\
- \\
0.4\end{array}$ & $\begin{array}{c}- \\
- \\
0.4\end{array}$ & - & $\begin{array}{l}- \\
0.4 \\
-\end{array}$ & $\begin{array}{l}- \\
- \\
-\end{array}$ & $\begin{array}{l}- \\
- \\
-\end{array}$ & $\begin{array}{l}- \\
-\end{array}$ & $\begin{array}{l}- \\
- \\
-\end{array}$ & - & - & $\begin{array}{l}- \\
- \\
-\end{array}$ & - & $\begin{array}{c}- \\
- \\
0.4\end{array}$ & 2.4 \\
\hline $600-700$ & $\begin{array}{c}- \\
- \\
0.4\end{array}$ & $\begin{array}{l}- \\
-\end{array}$ & $\begin{array}{l}- \\
-\end{array}$ & $\begin{array}{l}- \\
- \\
-\end{array}$ & $\begin{array}{l}- \\
-\end{array}$ & $\begin{array}{l}- \\
- \\
-\end{array}$ & $\begin{array}{l}- \\
-\end{array}$ & $\begin{array}{l}- \\
-\end{array}$ & $\begin{array}{l}- \\
- \\
-\end{array}$ & $\begin{array}{l}- \\
-\end{array}$ & - & $\begin{array}{l}- \\
-\end{array}$ & - & $\begin{array}{c}- \\
- \\
0.4\end{array}$ & 2.3 \\
\hline $700-800$ & $\begin{array}{c}- \\
0.4 \\
2.6\end{array}$ & $\begin{array}{c}- \\
0.8 \\
12.4\end{array}$ & $\begin{array}{l}- \\
1.5 \\
-\end{array}$ & $\begin{array}{l}- \\
- \\
-\end{array}$ & - & $\begin{array}{c}7.2 \\
- \\
-\end{array}$ & - & $\begin{array}{l}- \\
-\end{array}$ & $\begin{array}{c}- \\
- \\
0.8\end{array}$ & - & $\begin{array}{l}- \\
- \\
-\end{array}$ & $\begin{array}{l}- \\
-\end{array}$ & $\begin{array}{l}- \\
-\end{array}$ & $\begin{array}{l}0.8 \\
1.1 \\
0.4\end{array}$ & 4.1 \\
\hline $800-900$ & $\begin{array}{l}1.3 \\
0.8 \\
0.4\end{array}$ & $\begin{array}{c}- \\
- \\
1.3\end{array}$ & $\begin{array}{c}- \\
0.4 \\
1.3\end{array}$ & - & $\begin{array}{c}0.4 \\
- \\
0.8\end{array}$ & $\begin{array}{c}1.3 \\
- \\
-\end{array}$ & - & $\begin{array}{l}- \\
- \\
-\end{array}$ & $\begin{array}{c}- \\
- \\
1.3\end{array}$ & $\begin{array}{l}- \\
-\end{array}$ & - & $\begin{array}{l}- \\
-\end{array}$ & $\begin{array}{l}- \\
- \\
-\end{array}$ & $\begin{array}{c}- \\
3.4 \\
5.5\end{array}$ & 0.8 \\
\hline $900-1000$ & $\begin{array}{c}- \\
0.4 \\
2.4\end{array}$ & $\begin{array}{l}0.8 \\
1.2 \\
2.8\end{array}$ & - & $\begin{array}{l}- \\
- \\
-\end{array}$ & - & $\begin{array}{c}0.4 \\
- \\
-\end{array}$ & - & $\begin{array}{c}- \\
2.4 \\
-\end{array}$ & $\begin{array}{c}0.8 \\
- \\
0.4\end{array}$ & - & - & - & $\begin{array}{l}- \\
-\end{array}$ & - & 0.8 \\
\hline $1400-1600$ & $\begin{array}{l}0.4 \\
0.4 \\
1.2\end{array}$ & $\begin{array}{c}0.2 \\
1.8 \\
14.3\end{array}$ & $\begin{array}{c}0.4 \\
- \\
-\end{array}$ & $\begin{array}{c}0.2 \\
- \\
-\end{array}$ & $\begin{array}{c}0.6 \\
- \\
26.2\end{array}$ & $\begin{array}{c}0.4 \\
- \\
-\end{array}$ & $\begin{array}{l}0.8 \\
0.4 \\
0.4\end{array}$ & $\begin{array}{l}- \\
- \\
-\end{array}$ & $\begin{array}{l}0.2 \\
0.8 \\
0.8\end{array}$ & $\begin{array}{l}- \\
-\end{array}$ & $\begin{array}{l}- \\
- \\
-\end{array}$ & $\begin{array}{l}- \\
- \\
-\end{array}$ & - & $\begin{array}{c}0.6 \\
1.4 \\
10.8\end{array}$ & 3.2 \\
\hline $1600-1800$ & $\begin{array}{c}0.4 \\
- \\
1.2\end{array}$ & $\begin{array}{l}0.2 \\
0.2 \\
3.8\end{array}$ & $\begin{array}{c}- \\
0.4 \\
-\end{array}$ & $\begin{array}{l}- \\
-\end{array}$ & $\begin{array}{l}- \\
-\end{array}$ & $\begin{array}{l}- \\
- \\
-\end{array}$ & $\begin{array}{l}- \\
-\end{array}$ & $\begin{array}{l}- \\
- \\
-\end{array}$ & $\begin{array}{l} \\
-\end{array}$ & $\begin{array}{l}- \\
-\end{array}$ & $\begin{array}{l}- \\
-\end{array}$ & $\begin{array}{l} \\
- \\
-\end{array}$ & - & $\begin{array}{c}4.0 \\
0.2 \\
36.2\end{array}$ & 8.4 \\
\hline $1800-2000$ & $\begin{array}{l}- \\
- \\
-\end{array}$ & $\begin{array}{c}- \\
0.2 \\
-\end{array}$ & $\begin{array}{l}- \\
- \\
-\end{array}$ & $\begin{array}{l} \\
- \\
-\end{array}$ & $\begin{array}{l}- \\
-\end{array}$ & $\begin{array}{l}- \\
- \\
-\end{array}$ & $\begin{array}{l}- \\
-\end{array}$ & $\begin{array}{l}- \\
- \\
-\end{array}$ & $\begin{array}{l} \\
- \\
-\end{array}$ & $\begin{array}{l}- \\
-\end{array}$ & $\begin{array}{l} \\
- \\
-\end{array}$ & $\begin{array}{l}- \\
- \\
-\end{array}$ & $\begin{array}{l}- \\
- \\
-\end{array}$ & $\begin{array}{c}2.9 \\
2.9 \\
25.5\end{array}$ & 0.4 \\
\hline
\end{tabular}

Species composition and abundances of the halocyprid and myodocopid assemblage in the nighttime profile. Abundances in are given as numbers per $1000 \mathrm{~m}^{3}$ in each sampling stratum and the data for each species are subdivided into females (upper), males (middle) and juveniles (lower). The species are presented in order of abundance and depth of occurrence. The shaded depths indicate where the mean dissolved oxygen concentrations are $<8.0 \mathrm{mls} \mathrm{O}_{2} \cdot \mathrm{l}^{-1}$. The break at $1000 \mathrm{~m}$ in the table indicates where bathypelagic sampling was restricted to daytime. 


\begin{tabular}{|c|c|c|c|c|c|c|c|c|c|c|c|c|c|c|c|c|c|c|c|}
\hline & 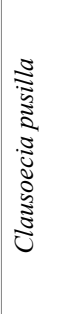 & 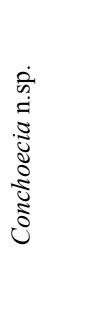 & 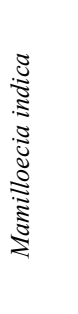 & 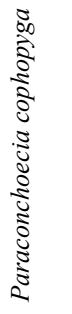 & 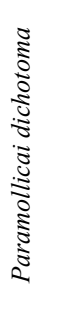 & 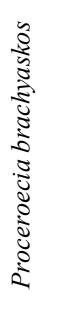 & 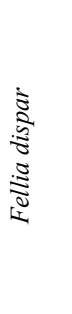 & 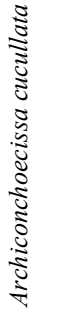 & 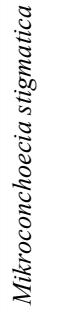 & 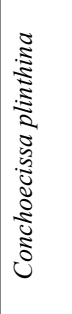 & 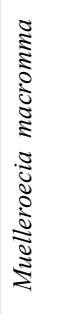 & 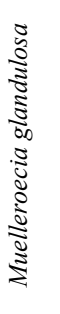 & 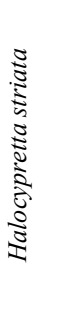 & 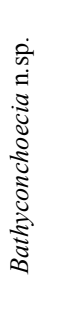 & 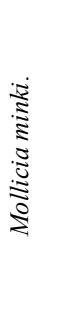 & 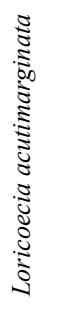 & 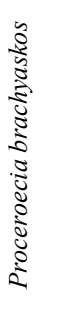 & 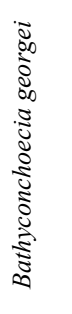 & 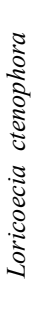 \\
\hline \multirow{3}{*}{$1400-1600$} & 10.2 & - & 68 & 2.0 & 3.9 & - & 0.2 & 0.2 & 1.2 & 4.7 & 1.2 & - & - & - & - & - & - & 0.2 & 0.2 \\
\hline & 11.5 & - & 30.5 & 3.3 & 1.6 & 0.2 & 2.2 & - & 1.6 & 4.7 & 2.9 & - & - & 0.2 & 0.2 & - & 0.2 & - & - \\
\hline & 4.3 & 4.3 & 40.1 & 3.7 & 6.1 & 2.2 & 3.3 & - & 22.7 & - & 3.7 & - & - & - & - & - & 2.2 & - & - \\
\hline \multirow{3}{*}{$1600-1800$} & 1.8 & 5.6 & 6.0 & 3.4 & 0.6 & - & - & - & 1.2 & - & - & 13.1 & 0.8 & - & - & & - & - & - \\
\hline & 7.6 & 3.4 & 7.0 & 5.8 & 0.2 & - & - & - & 2.2 & 0.4 & - & 1.0 & 3.4 & - & 0.4 & & - & - & - \\
\hline & 35.2 & 31 & 12.3 & 10.7 & 12.1 & - & - & - & 0.6 & - & - & 1.4 & 36.2 & 0.2 & - & & - & - & - \\
\hline \multirow{3}{*}{$1800-2000$} & - & 4.6 & 0.2 & 1.3 & - & - & - & 0.2 & 1.3 & - & - & 4.6 & 0.8 & 0.4 & 0.6 & & - & - & - \\
\hline & - & 2.5 & - & 0.8 & 0.2 & - & - & - & 1.3 & - & - & 2.3 & 1.1 & - & 1.0 & & - & - & - \\
\hline & 1.7 & 55.4 & 1.3 & 2.1 & 1.7 & - & - & - & 0.6 & - & - & 1.7 & 15.6 & 0.4 & 0.4 & & - & - & - \\
\hline
\end{tabular}

dissolved oxygen. A few juveniles of Alacia alata were collected from 200-400 m; in the Atlantic this species is a subdominant in the Mauritanian upwelling region off Northwest Africa, and so may be adapted to exploiting upwelling systems (c.f. the copepod Calanoides carinatus (Smith, 1982; Verheye, 1991)). Between 400-900 m the total catches were tiny and contained very few ostracods; it is possible that even the few ostracods specimens that were caught at these depths were contaminants that had leaked into the closed nets as they were being retrieved. At 900-1000m single specimens of Mikroconchoecia acuticosta and Gaussicia subedentata were collected. This is the first record of M. acuticosta from outside the North Atlantic (Angel et al., 2007). The first specimens of bathypelagic species began to be encountered at 1200-1400 m, namely Conchoecissa plinthina, Conchoecissa symmetrica, Muelleroecia aff. macromma, Deeveyoecia arcuata, Macroconchoecia macroreticulata, Mamilloecia indica and Procera brachyaskos. All these species were either rare or absent from the Drapun and Smith (2012) samples.

\section{Species profiles}

The day and night profiles of the ten most abundant species expressed as percentages of the total population in the upper $1000 \mathrm{~m}$ are plotted in Figures 4 and 5. The populations of all ten species were concentrated in the upper 200 to $400 \mathrm{~m}$. The profiles show that only one species, Cypridina sp., showed clear evidence of diel vertical migration. Four other species showed slight and rather inconclusive evidence for upward migration at night (Archiconchoecia striata, Euconchoecia omanensis, Pseudoconchoecia concentrica and Proceroecia procera). A small percentage of the population of Conchoecetta giesbrechti migrated up at night from 200-300 m to above $200 \mathrm{~m}$, but did not migrate up through the oxycline to above $100 \mathrm{~m}$. The profile for Metaconchoecia inflata indicates it may have been undertaking a slight reverse migration. Note that Smith et al. (1998) reported that none of the mesozooplankton species they studied undertook diel ver- tical migrations where there was a strong OMZ.

Three of the less abundant species, Euconchoecia hormuzensis, Conchoecia hyalophyllum and Porroecia parthenoda were only encountered at night, and the few specimens of Alacia alata sampled were only caught by day. Peak abundances of four species were at 100-200 m near the top of the OMZ - Discoconchoecia elegans, Archiconchoecia striata, Conchoecia giesbrechti and Metaconchoecia acuta. These species must have either been able to tolerate very low concentrations of oxygen, or were undertaking vertical migrations that were unsynchronised with the light cycle. At depths between 200 and $1000 \mathrm{~m}$ Metaconchoecia inflata was the only species that was relatively abundant. It is notable that between $300-1000 \mathrm{~m}$ where there were very low ostracod abundances, there was a complete absence of any mesopelagic species; large mesopelagic assemblages are a characteristic feature of the ostracod populations in the North Atlantic (Angel et al 2007).

Comparing the profile of oxygen concentration with the profiles of the halocyprid abundances (Table 1 and Figure 2), it can be seen that Euconchoecia omanensis was almost entirely restricted to the well-oxygenated water (Figure 4). Cypridina dentata and Archiconchoecia striata were migrating across the oxycline at $\sim 100 \mathrm{~m}$ (Figure 4). Several species were restricted to below 100 $\mathrm{m}$ where the oxygen concentrations were low i.e. Conchoecetta giesbrechti, Discoconchoecia elegans and the two Metaconchoecia species (Figures 4 and 5). These species occur in much deeper water in the Atlantic, so why, if they are tolerant of such low oxygen conditions, are they absent from deeper water in the Gulf of Oman? This absence of a mesopelagic ostracod assemblage was not characteristic of the copepod populations reported on by Wishner et al. (2008) who showed the copepods were partitioning the whole of the OMZ in the waters outside the Gulf. Predation is unlikely to be the factor limiting the abundances of ostracods, because the micronektonic predators that occupy these depths by the day are not feeding (Herring et al, 1998). A possible fac- 
tor that cannot be ruled out is that high concentrations of sulphide ions generated by the anaerobic decomposition may have attained levels that are toxic to the halocyprids, but no measurements of sulphide ion concentrations were made.
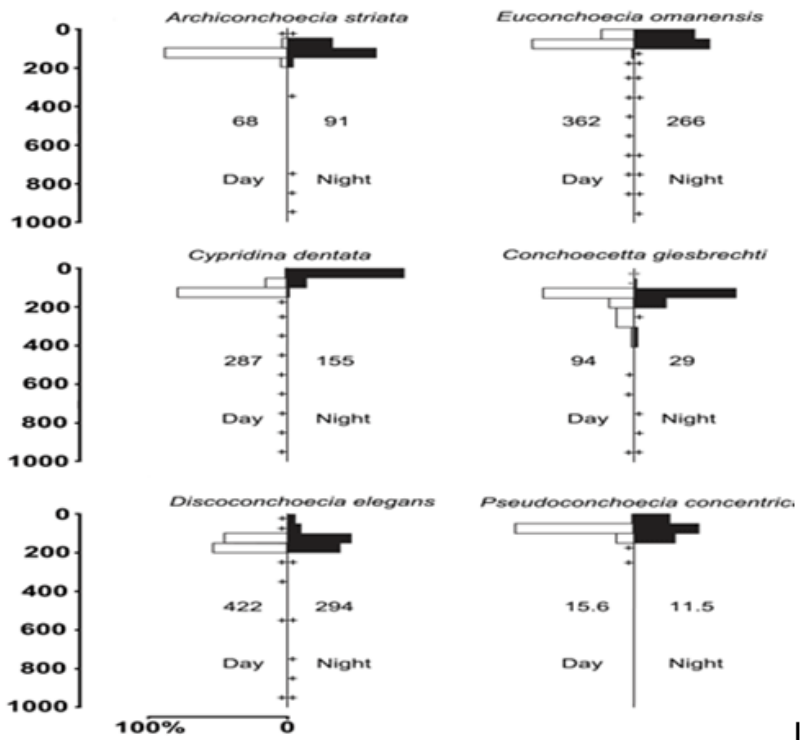

।

Figure 4: Day and night abundance profiles in the upper $1000 \mathrm{~m}$ of Archiconchoecia striata, Euconchoecia omanensis, Cypridina dentata, Conchoecietta giesbrechti, Discoconchoecia aff. elegans and Pseudoconchoecia concentrica, expressed as the percentages of the total number caught in each set of samples. The numbers indicate the estimated number of each species per $\mathrm{m}^{2}$ in each profile. + indicates presence at depths where the percentage was too small to be plotted (i.e. $<0.1 \%$ ).
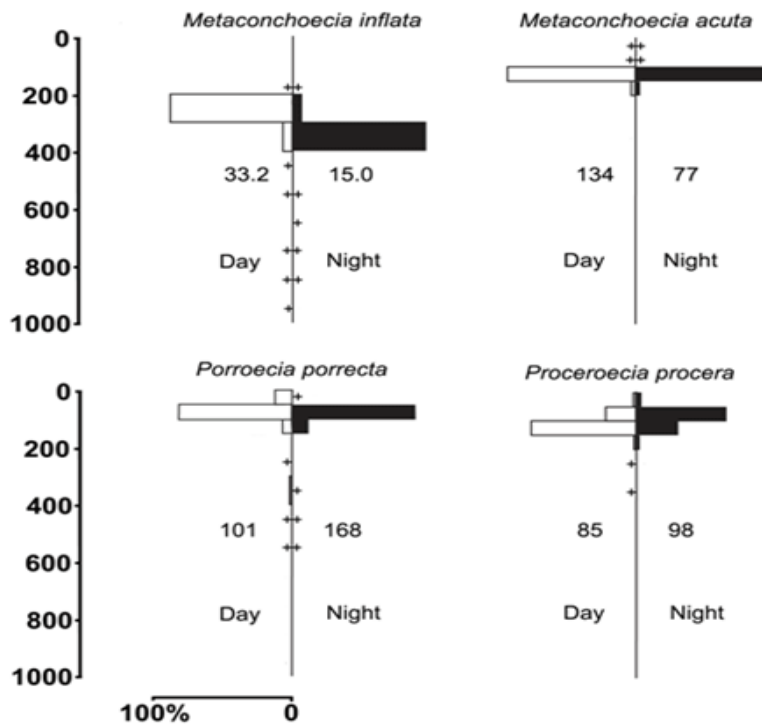

Figure 5: Day and night abundance profiles in the upper $1000 \mathrm{~m}$ of Metaconchoecia inflata, Metaconchoecia acuta, Porroecia porrecta and Proceroecia procera, expressed as the percentages of the total number caught in each set of samples. The numbers indicate the estimated number of each species per $\mathrm{m}^{2}$ in each profile. + indicates presence at depths where the percentage was too small to be plotted (i.e. $<0.1 \%$ ).
In the three deepest night-time tows there were several bathypelagic species that have not previously been recorded from the Indian Ocean. Two of these species are novel (Conchoecia sp., Bathyconchoecia sp.) and are still to be described. One has recently been described (Mamilloecia indica, Graves, (2012)). Three others are poorly known (Fellia dispar, Bathyconchoecia georgei and Mollicia minki), and a fourth (Halocypretta striata Müller, 1906) has been recently been re-described (Angel, 2013).

\section{Taxonomic discussion}

Drapun and Smith (2012) samples had a broad geographical coverage, but were restricted bathymetrically to the upper $1000 \mathrm{~m}$, and resulted from the filtration of much smaller volumes of water. Their MOC1 sampler was fitted with a much finer mesh $200 \mu \mathrm{m}$ mesh compared to the $320 \mu \mathrm{m}$ mesh of the RMT I. So their samples included many more of the early instars that cannot be identified to species. We record several species were not reported by Drapun and Smith (2012), the majority of which were collected at depths $>1000 \mathrm{~m}$ (marked † in Table 3).

There are also differences resulting from taxonomic interpretations. Graves (2011) critically examined the Euconchoecia species from these samples describing them as two novel species and showing them to be are distinct from the Atlantic species. This casts doubts on the accuracy of many of the published records of E. chierchiae and E. aculeata certainly from regions outside the Atlantic. Euconchoecia is a taxonomically difficult genus of small species that is in drastic need of revision. Ecologically, it is important genus particularly at low latitudes in the Indo-Pacific, where it is often numerically dominant in inshore plankton assemblages. Drapun and Smith (2012) reported three Euconchoecia species.

Similarly the taxonomy of the genus Cypridina is in a chaotic state (Kornicker, 1991). The species that occurs in the Gulf of Oman has been identified as Cypridina dentata (e.g. Daniel and Jothinayagam 1979), but until the genus has been re-assessed the identity of the species recorded here remains uncertain. Drapun and Smith (2012) did not include it in their study as it is a myodocopid. However, the total number they collected in all their samples was just 25 (Drapun, personal communication). So, either it is predominantly an inshore species, or its swarms are episodic (Daniel and Jothinayagam 1979).

We have recorded only a single species of Discoconchoecia that we have tentatively referred to as D. aff. elegans. Drapun and Smith (2012) record three species - D. discophora (Müller, 1906), D. aff. elegans and D. tamensis (Poulsen, 1973). D. discophora was not present in the Gulf of Oman, but both the other two species may have been present. Poulsen's (1973) original description of $D$. tamensis is incomplete and is based on a single male specimen from $7^{\circ} 46^{\prime} \mathrm{S} 131^{\circ} 22^{\prime} \mathrm{W}$ (Poulsen, 1973). Drapun and Smith (2012) provide comprehensive descriptions of their species, but their identification of $D$. tamensis can only be verified by re-examining the unique type specimen. In the Gulf of Oman the shallow specimens we have identified as D. aff. elegans match Drapun and Smith's description of $D$. tamensis notably in carapace size. The deeper specimens match their description of $D$. aff. elegans. The 'elegans' species complex is globally widespread but 
its taxonomy needs to be resolved. Stepien et al., (2015) have recently made an important first step in re-described $D$. elegans from its type locality near the Lofoten Islands off Norway and high latitudes in the Arctic.

Chavtur and Stovbun (2003) when establishing several sibling species previously ascribed to $A$, striata, suggested that Archiconchoecia striata sensu George (1979) from the Northwest Indian Ocean, which is the form present in our samples, should be regarded as a novel species.

Graves (2012) described a novel genus and species Mamilloecia indica from the Gulf of Oman. This species that is identical to Paraconchoecia mamillata sensu Drapun and Smith (2012) (see their Figure 48A). Graves (2012) gives a detailed description of Paraconchoecia spinifera, which is the designated type species for the genus and shows that the species in the mamillata are markedly different, and so classifies Conchoecia mamillata sensu Müller 1906 and Conchoecia nanomamillata sensu Deevey and Brooks 1970 in her new genus.

Metaconchoecia is another problematic halocyprid genus. Drapun and Smith (2012) did not attempt to identify their specimens, and the recent revision of Metaconchoecia (Chavtur and Angel, 2011) did not include any species previously reported from the Indian Ocean. Thus our specimens of M. inflata need reevaluation.

Otherwise most of the species recorded by Drapun and Smith (2012) that were absent from our Gulf of Oman samples, belong to the mesopelagic assemblage that was absent from the OMZ in the Gulf of Oman.

\section{Comparison with North Atlantic profiles from $30^{\circ} \mathrm{N}$,} $23^{\circ} \mathrm{W}$

Comparison with identically sampled profiles of halocyprid species from a similar latitude $\left(30^{\circ} \mathrm{N}, 23^{\circ} \mathrm{W}\right)$ in the North Atlantic (Angel, 1979) indicate substantial impact the OMZ has on the ostracod populations in the Gulf. At $30^{\circ} \mathrm{N} 23^{\circ} \mathrm{W}$ oxygen concentrations are consistently high throughout the water column and 69 species of halocyprid were collected between the surface and $2000 \mathrm{~m}$ (c.f. 41 in the Gulf of Oman). The two data seta have only 13 species in common, namely Discoconchoecia elegans, Proceroecia procera, Proceroecia brachyaskos, Porroecia porrecta, Porroecia parthenoda, Loricoecia ctenophora, Gaussicia subedentata, Metaconchoecia inflata, Archiconchoecia striata, Conchoecia hyalophyllum, the small form of Archiconchoecissa cucullata, Mikroconchoecia stigmatica, Orthoconchoecia atlantica and Deeveyoecia arcuata. The description of Mamilloecia indica (Graves, 2012), which is a cryptic version of an Atlantic species, suggests that critical appraisal of others of these species that appear to be common to both data sets may also reveal further cryptic species.

In the Atlantic many halocyprid species undertake diel vertical migration, and very few specimens and/or species are caught in the upper $50 \mathrm{~m}$ by day. But at night vertical migrations result in substantial increases in both species richness and abundances of halocyprids. In the Gulf of Oman the near-surface densities of the ostracods were higher by day than by night; so some of the species were undertaking reverse migrations, pos- sibly in response to the large influx of migratory micronektonic predators. There is another possible alternative explanation for the night-time catches being relatively low. The Cypridina species that was so abundant in the upper $100 \mathrm{~m}$ is brightly luminescent. Its luminescence will have brightly illuminated the net brightly, increasing net avoidance. However, one characteristic of halocyprids is their lack of eyes, but this does not preclude them from having a general sensitivity to light; indeed the fact that several species undertake diel vertical migrations synchronised with the light cycle does imply they have an ability to detect light levels.

There is a marked contrast between the ostracod assemblages in the upper $100 \mathrm{~m}$ between the two oceans. In the Gulf, the near-surface assemblage is dominated by species that brood their embryos within the carapace (viz Euconchoecia spp and Cypridina dentata). In the Atlantic all the halocyprids broadcast their eggs freely into the water, and brooders, like the myodocopids, are either absent or rare (although a Euconchoecia species is abundant in the inshore waters along the south-east coast of the North America (Baker, 1975; Baker et al.. 1977)). In the eastern North Atlantic the niche occupied by Euconchoecia species is occupied by Porroecia spinirostris (Claus, 1874), Mikroconchoecia curta (Lubbock, 1860), M. echinulata (Müller 1906), and Halocypris inflata Dana 1849. All four of these species occur in the Indian Ocean outside regions where there is an OMZ (Drapun and Smith (2012).

Figure 6 illustrates the marked contrast between the abundances and species richness of the ostracods between the two oceans. In the North Atlantic abundances and species numbers are very low in the upper $25 \mathrm{~m}$ by day, but increase substantially at night as a result of upward migration predominantly from daytime depths of 200-400 m. Whereas in the Gulf of Oman total ostracod abundances were much higher in the upper 200 $\mathrm{m}$, but decreased dramatically in the OMZ below $200 \mathrm{~m}$. Below $1000 \mathrm{~m}$ the abundances began to increase as the dissolved oxygen levels increased; at the deepest depths sampled the abundances were equivalent to, or maybe began to exceed those in the Atlantic, possibly as a result of higher organic fluxes.

Figure 7 illustrates the striking differences between that the profiles of species richness in the two oceans. In the Atlantic species richness increases steadily with depth and only shows some signs of a decline at the greatest depth sampled, 1500-2000 $\mathrm{m}$. Below the OMZ in the Gulf of Oman species richness showed the first signs of increase below $1200 \mathrm{~m}$ and at $1800-2000 \mathrm{~m}$ had risen to become similar to that in the North Atlantic.

Thus, the presence of the strong OMZ results in an impoverished halocyprid fauna in the Gulf of Oman, although the low oxygen concentrations may not have been the only limiting factor. Striking absentees from the Gulf include the large myodocopid species of Gigantocypris and Macrocypridina. Canon (1940) described Gigantocypris dracontovalis from the John Murray Expedition's collections, but this is a species that is abyssopelagic or benthopelagic in the Atlantic occurring at depths $>3000 \mathrm{~m}$ (Angel 2010).

Elsewhere in the Arabian Sea Wishner et al., (2008) have demonstrated that calanoid copepods partition the OMZ into three zones (300-500 m, 500-700 m and 700-1000 m); But we found no equivalent zonation in our halocyrid data from the Gulf of 


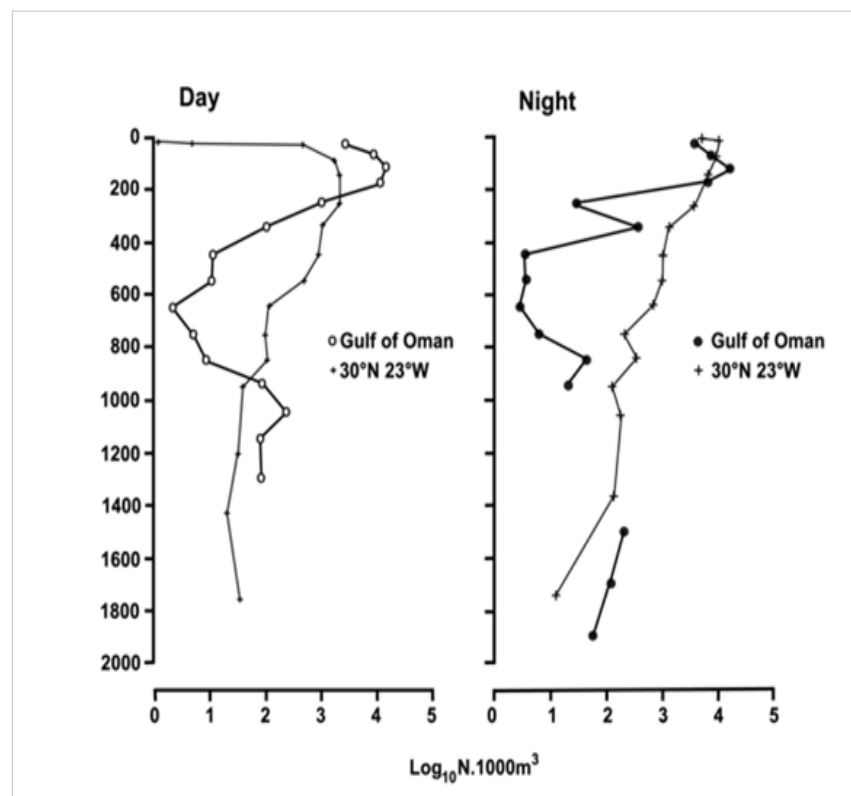

Figure 6:Comparison of day and night abundances of halocyprid ostracods expressed as $\log 10$ numbers per $1000 \mathrm{~m}^{3}$ in the Gulf of Oman and at $30^{\circ} \mathrm{N} 23^{\circ} \mathrm{W}$ in the North-east Atlantic.

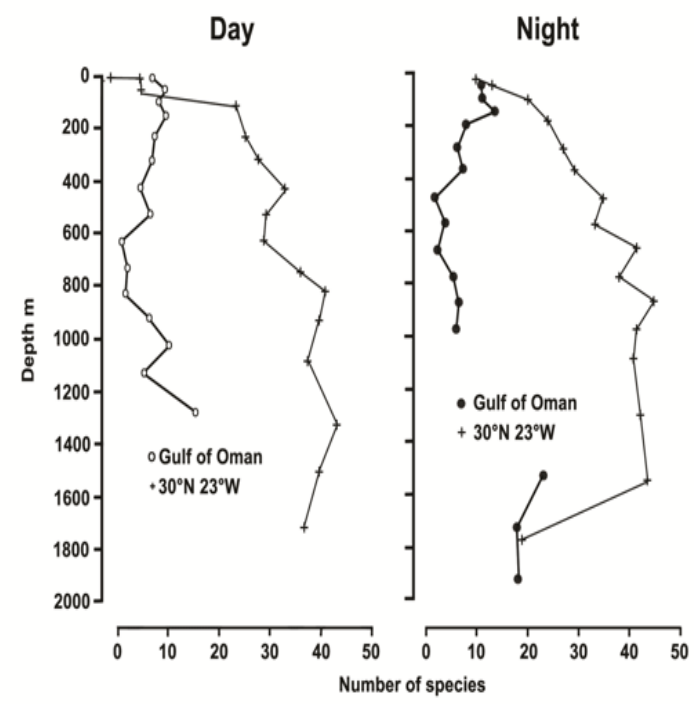

Figure 7: Comparison of profiles of halocyprid species richness by day and by night in the Gulf of Oman and at $30^{\circ} \mathrm{N} 23^{\circ} \mathrm{W}$ in the North-east Atlantic.

Oman.

\section{Conclusions}

In the Gulf of Oman the planktonic ostracod populations are numerically abundant but poor in species, both in the windmixed layer and in the upper $100 \mathrm{~m}$ of the OMZ. Within the core of the OMZ the ostracod populations are exceedingly sparse. At depths below the OMZ at $1100 \mathrm{~m}$, the abundances began to in- crease, becoming similar to those observed in the North Atlantic as the availability of oxygen increased. Throughout the water column species richness is much lower in the Gulf than in the Atlantic, because of the absence of a mesopelagic assemblage. The ranges of the diel vertical migration being undertaken by several halocyprid species were restricted to within the upper $200 \mathrm{~m}$. These results supplement those the recent studies of the copepod faunas in the central region of the Arabian Sea (Smith et al., 1998;Padmavati et al., 1998; Wishner et al., 2008)

Several novel and poorly-known species were present. There are fewer species in common between the Gulf and the Atlantic faunas than had been expected. The epipelagic ostracod assemblage is dominated by species with females that brood their eggs and early juveniles stages within their carapaces.

\section{Acknowledgements}

We thank the captain and crew of RRS Charles Darwin and the scientists participating in the "Scheherazade" Cruise, particularly the Principal Scientist Professor Howard Roe for making the samples available to us. This research contributed to the $\mathrm{PhD}$ thesis of Carol Graves, who acknowledges the support given to her by Dr Rob Hughes Queen Mary University and particularly by Professor Geoff Boxshall at the Natural History Museum, London. Martin Angel gratefully acknowledges the continuing support given to him by the National Oceanography Centre, Southampton and by the Natural History Museum in appointing him an Honorary Scientific Associate. The authors would like to express their thanks to Dr Inna Drapun and Professor Geoff Boxshall for their critical reading of a preliminary draft of this paper.

\section{References}

1. Angel MV. Planktonic ostracods from the Canary Island region: their depth distributions, diurnal migrations, and community organisation. Journal of the Marine Biological Association of the United Kingdom. 1969;49(2):515-553.

2. Angel MV. Studies on Atlantic halocyprid ostracods: their vertical distributions and community structure in the central gyre region along latitude $30^{\circ} \mathrm{N}$ from off Africa to Bermuda. Progress in Oceanography. 1979;8(1-2):3-124.

3. Angel MV. The diel migrations and distributions within a mesopelagic community in the North-east Atlantic. 3. Planktonic ostracods, a stable component in the community. Progress in Oceanography. 1984;13(34):319-351

4. Angel MV. Towards a full inventory of planktonic Ostracoda (Crustacea) for the subtropical Northwestern Atlantic Ocean. Deep-Sea Research part II. 2010;57(24-26):2173-2188.

5. Angel MV. Planktonic ostracods (Myodocopa: Halocyprididae) from abyssopelagic depths in the Atlantic, North Pacific and Gulf of Oman: Chavturia abyssopelagica (n. gen., n. sp.), Halocypretta profunda (n. sp.), Halocypretta parvirostrata Chavtur and Stovbun, 2008 and Halocypretta striata (Müller, 1906). Zootaxa. 2013;3709:401-431 “.

6. Angel MV, Hargreaves P, Kirkpatrick P, Domanski P. Low variability in planktonic and micronektonic populations at $1000 \mathrm{~m}$ depth in the vicinity of $42^{\circ} \mathrm{N} 17^{\circ} \mathrm{W}$; evidence against diel vertical migratory behavior in the majority of species. Biological Oceanography. 1982;1(3):287- 
319.

7. Angel MV, Fasham MJR. SOND Cruise 1965: Factor and cluster analyses of the plankton results, a general summary. Journal of the Marine Biological Association of the United Kingdom. 1973;53(1):185-231.

8. Angel MV, Fasham MJR. SOND Cruise 1965: Further factor analyses of the plankton data. Journal of the Marine Biological Association of the United Kingdom. 1974;54(04):879-894. doi:10.1017/ S0025315400057635

9. Angel MV, Fasham MJR. Analysis of the vertical and geographic distribution of the abundant species of planktonic ostracods in the Northeast Atlantic. Journal of the Marine Biological Association of the United Kingdom. 1975;55(3): 709-737.

10.Angel MV, Blachowiak-Samolyk K, Drapun I, Castillo R. Changes in the composition of planktonic ostracod populations across a range of latitudes in the North-east Atlantic. Progress in Oceanography. 2007;73(1):60-78.

11. Baker JH. (1975) Distribution, Ecology and Life Histories of Selected Cypridinacea (Myodocopida, Ostracoda) from the Southern California Mainland Shelf. PhD Thesis, Department of Biology, University of Houston, Houston, Texas.

12. Baker JH, Jones TL, Salinas J. Occurrence of Euconchoecia chierchiae Müller 1890 (Ostracoda, Halocyprididae) in Cedar Bayou, Cambers County, Texas. Chesapeake Science. 1977;18(4):394. doi: $10.2307 / 1350597$

13. Boos WR, Emanuel KA. Annual intensification of the Somali jet in a quasi-equilibrium framework: Observation composites. Quarterly Journal of the Royal Meteorological Society. 2009;135(639):319-335. doi:10.1002/qj.388

14. Cannon HG. (1940) Ostracoda. Reports of the John Murray Expedition 1933-1934, 6, 319-325.

15. Chavtur VG, Angel MV. Revision of Metaconchoecia (Ostracoda: Halocyprididae) and the designation of two new tribes Conchoeciini and Metaconchoeciini. Zootaxa. 2011;2857:1-87.

16. Chavtur VG, Stovbun GG. Revision of pelagic ostracods of the subfamily Archiconchoecinae. Publications of the Seto Marine Biological Laboratory. 2003;39(4/6):139-219.

17.Daniel A, Jothinayagam JT. Observations of the nocturnal swarming of the planktonic ostracod Cypridina dentata (Müller) for mating in the Northern Arabian Sea. Bulletin of the Zoological Survey of India. 1979;2(1):25-28.

18. Drapun I, Smith S. (2012) Halocyprid Ostracods of the Arabian Sea Region, Sultan Qaboos University, Muscat, Oman.

19. Fasham MJR, Angel MV. The relationship of the zoogeographic distributions of the planktonic ostracods in the North-east Atlantic to the water masses. Journal of the Marine Biological Association of the United Kingdom. 1975;55(3): 739-757.

20.George J. (1969) A preliminary report on the distribution and abundance of planktonic ostracods in the Indian Ocean. Bulletin of the National Institute of Science India, 38, 641-648.

21. George J. Redescription of Archiconchoecia striata Muller (Ostracoda, Halocyprididae) and its distribution in the Northern Indian Ocean. Crustaceana. 1979;36(2):123-128. doi:10.1163/156854079X00302

22. George J. Nair VR. Planktonic ostracods of the Northern Indian
Ocean. Mahasagar Bulletin of the National Institute of Oceanography. 1980;13(1):29-44.

23. Graves CD. Redescription of Euconchoecia chierchiae Müller, 1890 and Euconchoecia aculeata (Scott, 1894) (Halocyprididae: Ostracoda) from the Atlantic, and descriptions of two novel species of Euconchoecia Müller 1890, from the Gulf of Oman. Journal of Natural History. 2011;45(31-32):1937-1981.

24. Graves C. Mamilloecia indica (Halocyprididae: Ostracoda) a new genus and species from the Northwest Indian Ocean. Journal of Natural History. 2012;46(9-10):517-556.

25. Herring PJ, Fasham MJR, Weeks AR, Hemmings JCP, Roe HSJ, Angel MV. Across-slope relations between the biological populations, the euphotic zone and the oxygen minimum layer off the coast of Oman during the southwest monsoon (August, 1994). Progress in Oceanography. 1998;41(1):69 - 109.

26. Herring, P.J., Howell, P.R. and Pugh, P.R. (1999) Scheherazade - an interdisciplinary study of the Gulf of Oman, Strait of Hormuz and southern Arabian Gulf, Charles Darwin Cruise 104, 12 Feb-30 Apr 1997. No 16, Fish, decapod shrimps and siphonophores: abundances and size data. Leg 1, 12 Feb-Mar 1997 (Unpublished manuscript).

27. James, C.M. (1975) Studies on the Ostracoda of the Indian Ocean. PhD Thesis, University of Kerala, India.

28. Kornicker, L.S. (1991) Myodocopid Ostracoda of Enewetak and Bikini Atolls. Smithsonian Contributions to Zoology, 505, 1-140.

29. Leveau, M. (1967) Ostracodes pélagique du sud-ouest de l’Océan Indien (Région de Tuléar). Recueil des travaux de la Station Marine d'Endoumme-Marseille (Fax. hors. série. suppl.), 6, 63-70.

30. Morrison JM, Codispoti LA, Gaurin S, Jones B, Magnhnani V, Zheng Z. Seasonal variation of hydrographic and nutrient fields during the US JGOFS Arabian Sea Process Study. Deep Sea Research Part II: Topical Studies in Oceanography. 1998;45(10-11):2053-2101.

31. Morrison JM, Codispoti LA, Smith SL, Wishner K, Flagg C, Gardner WD, et al. The oxygen minimum zone in the Arabian Sea during 1995. Deep Sea Research Part II: Topical Studies in Oceanography. 1999;46(89):1903-1931.

32. Nair VR, Madhupratap M. Latitudinal range of epiplanktonic Chaetognatha and Ostracoda in the Western tropical Indian Ocean. Hydrobiologia. 1984;112(3):209-216.

33. Naqvi, S.W.A., Naik, H. and Narvekar, P.V. (2003) the Arabian Sea. In Biogeochemistry of Marine Systems, Black, E and Shimmield, G (eds) Biological Sciences Series, 157-207.

34. Naqvi SWA, Moffet JW, Gauns MU, Narvekar PV, Pratihary A, Naik H, et al. The Arabian Sea as a high-nutrient, low-chlorophyll region during the late Southwest Monsoon. Biogeosciences. 2010;7(7):2091-2100.

35. Padmavati G, Haridas P, Nair KKC, Gopalkrishnan TC, Shiney P, Madhuptratap M. Vertical distribution of mesozooplankton in the central and eastern Arabian Sea during the winter monsoons. Journal of Plankton Research. 1998;20(2):343-354

36. Poulsen EM. Ostracoda-Myodocopa. Part 3b. Halocypriformes-Halocypridae. Conchoecinae. Dana Report. 1973;84:1-223.

37. Rixen T, Ittekkot V. Nitrogen deficits in the Arabian Sea, implications from a three component mixing analysis. Deep Sea Research Part II: Topical Studies in Oceanography. 2005;52(14-15):1879-1891.

38. Roe HSJ, Shale DM. A new multiple rectangular midwater trawl 
$($ RMT1+8) and some modifications to the Institute of Oceanographic Sciences' RMT1+8. Marine Biology. 1979;50(3):283-288.

39. Roe HSJ, Baker Ade C, Carson RM, Wild R, Shale DM. Behaviour of the Institute of Oceanographic Sciences' rectangular midwater trawls: theoretical aspects and experimental observations. Marine Biology. 1980;56(3):247-259.

40. Roe HSJ, Griffiths G, Hartman M, Crisp NA. Variability in biological distribution and hydrography from concurrent acoustic Doppler current profiler and SeaSoar surveys. ICES Journal of Marine Science. 1996;53(2):131-138.

41. Smith SL. The northwestern Indian Ocean during the monsoons of 1979: distribution, abundance, and feeding of zooplankton. Deep Sea Research part A. Oceanographic Research Papers. 1982;29(11):13311353.

42. Smith S, Roman M, Wishner K, Gowing M, Codispoti LA, Barber R, et al. Seasonal response of zooplankton to monsoonal reversals in the Arabian Sea. Deep Sea Research Part II: Topical Studies in Oceanography. 1998;45(10-11): 2369-2403.

43. Smith SL, Madhupratap M. Mesoplankton of the Arabian Sea: Patterns influenced by seasons, upwelling and oxygen concentrations. Progress in Oceanography.2005;65(2-4):214-239.

44.Stępien A, Blachowiak-Samolyk K, Angel MV. A re-description of Discoconchoecia elegans (Sars, 1865) (Ostracoda: Halocyprididae) from high latitudes in the North Atlantic. Zootaxa. 2015;3995:66-77. doi.10.11646/zootaxa.3995.1.9

45. Van Couwelaar M, Angel MV, Madin LP. The distribution and biology of the swimming crab Charybdis smithii McLeay, 1838 (Crustacea; Brachyura; Portunidae) in the NW Indian Ocean. Deep-Sea Research Part II: Topical Studies in Oceanography. 1997;44(6-7):1251-1280.

46. Verheye HM. Short-term variability during an anchor station study in the southern Benguela upwelling system: Abundance, distribution and estimated production of mesozooplankton with special reference to Calanoides carinatus (Krøyer, 1849). Progress in Oceanography. 1991;28(1-2):91-199.

47.Wishner KF, Gelfmann C, Gowing MM, Outram DM, Rapien M, Williams RL. Vertical zonation and distributions of calanoid copepods through the lower oxycline of the Arabian Sea oxygen minimum zone. Progress in Oceanography. 2008;78(2):163-191. 